\title{
The Labor Agreements Between UAW And The Big Three Automakers- Good Economics Or Bad Economics?
}

John J. Lucas, Purdue University Calumet, USA

Jonathan M. Furdek, Purdue University Calumet, USA

\begin{abstract}
On October 10, 2007, the UAW membership ratified a landmark, 456-page labor agreement with General Motors. Following pattern bargaining, the UAW also reached agreement with Chrysler LLC and then Ford Motor Company. This paper will examine the major provisions of these groundbreaking labor agreements, including the creation of the Voluntary Employee Beneficiary Association (VEBA), the establishment of a two tier wage structure for newly hired workers, the job security provisions, the new wage package for hourly workers, and the shift to defined contribution plans for new hires. The paper will also provide an economic analysis of these labor agreements to consider both if the "Big Three" automakers can remain competitive in the global market and what will be their impact on the UAW and its membership.
\end{abstract}

Keywords: UAW, 2007 Negotiations, Labor Contracts

\section{BACKGROUND}

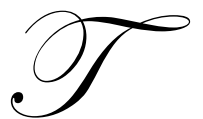

he 2007 labor negotiations among the Big Three automakers (General Motors, Chrysler LLC, and Ford Motor) and the United Autoworkers (UAW) proved to be historic, as well as controversial as they sought mutually to agree upon labor contracts that would "usher in a new era for the auto industry." Both parties realized the significance of attaining these groundbreaking labor agreements, in order for the American auto industry to survive and compete successfully in the global economy. For the UAW, with its declining membership of approximately 520,000, that once topped 1.5 million members, a commitment from the Big Three automakers for product investments to protect jobs and a new health care trust fund were major goals. On the other hand, the Big Three automakers, with their sluggish auto sales and declining market shares, a commitment to lower wages for some workers and an end to company-provided retiree health care were major objectives to be accomplished (McCraken and Kosdrosky). Following pattern bargaining, the UAW would begin these landmark negotiations with General Motors, followed by Chrysler LLC, and then conclude with the Ford Motor Company.

\section{GENERAL MOTORS -UNITED AUTOWORKERS NEGOTIATIONS}

The formal negotiations between General Motors (GM) and United Autoworkers (UAW) were complex and rigorous, as both parties struggled to attain their respective goals in order to reach a mutually agreed upon labor contract. For GM, the major goal was to "close the fundamental gaps that exist in our business." GM was the world's largest automaker leading the global industry in sales for the last seventy-six years. However, the title as the world's number one automaker had become increasingly difficult to maintain as its rival, Toyota Motor Corporation, continued to narrow the gap with its global auto sales. In 2007, GM narrowly maintained its title as the world's number one automaker as it sold 9.369 million vehicles, while Toyota Motor Corporation sold 9.366 million vehicles (Stoll, 2008). GM also went into negotiations seeking to reduce or erase a $\$ 25$ per-hour labor cost disparity of U.S. employee salaries compared with the labor costs of Japanese competitors. It was estimated that GM paid its workers \$73.26 an hour in wages and benefits (Durbin and Krisher, 2007). Additionally, GM wanted to unload from its balance sheet more than $\$ 50$ billion in debts owed to the UAW retiree health care and transfer that 
obligation to a union-controlled trust fund. GM estimated that this transfer of retiree health care would result in a savings of $\$ 1,200$ to 1,500 per car it sold, as compared to a car manufactured by its rival Toyota Motor Corporation (Stoll and McCracken, 2007). Therefore, GM's primary objective was to reduced both its labor and benefit expenditures, in order to compete effectively in the global market. GM's motivation lay in the fact that during the period 2004-2007, GM had lost nearly $\$ 50$ billion dollars, more than all the profit it had made in the past decade (Stoll, 2008).

For the UAW, its core strategy in entering negotiations was to secure a commitment from GM to protect jobs for its members. This goal was to be achieved by securing a GM investment commitment that would secure building current products, such as new vehicles or engines, as well as future generation of products at specified assembly facilities. If this goal were achieved, it would represent "unprecedented product guarantees" from GM, and also represent a significant departure from the union's strategy of saving jobs (McCracken and Kosdrosky). In order to secure the GM investment commitments, the UAW was fully aware that major concessions were necessary to achieve mutual agreement. What remained to be seen was the price it would cost the UAW in order to secure jobs for its membership. The UAW was also willing to listen and possibly agree, in principle, to the concept of a union-controlled health-care trust. However, the UAW recognized that complex negotiations were needed to resolve the financial issue of how much money GM was willing to commit to the trust fund (McCracken, 2007).

Formal negotiations, between GM and the UAW, commenced on July 23, 2007. As anticipated, the negotiations between the parties were contentious as both realized that their bargaining issues were very complex and challenging. In particular, the bargaining proposals in the areas of wages/benefits and job security were troublesome for both parties. These proposals were the mandatory bargaining subjects and, according to the provisions of the National Labor Relations Act, both parties were obliged to negotiate in good faith. The UAW and GM agreed upon a basic framework for the establishment of a health-care trust, referred to as the Voluntary Employee Benefit Association (VEBA), to manage the health costs of retirees. The establishment of VEBA was a permissible bargaining subject, since it applied to retirees and not to active members of the UAW (UAW.org, 2007).

On September 24, 2007, GM workers went on strike over job security and economic issues. This was the first strike against GM since 1998 and the first strike over a national labor agreement since 1970 (Stoll and McCracken). The strike was also significant because the UAW gave GM a nine-day contract extension which represented the longest in UAW history to avoid a strike (UAW.org, 2007). After a two-day strike, GM and the UAW reached a tentative agreement which contained "groundbreaking" contractual provisions.

One significant groundbreaking provision was the creation of VEBA which shifted $\$ 51$ billion in healthcare obligations for GM retirees to a union-operated trust fund (Spector, McCracken, and Stoll, 2007). Commencing in January 2008, GM would contribute $\$ 51$ billion and another $\$ 5.4$ billion to cover retirees' health care expenditures until VEBA was fully operating in 2010. Also, GM would contribute twenty additional $\$ 165$ million payments to a maximum amount of 1.6 billion, if the funding level of VEBA was insufficient over the next twenty-five years (Durbin and Krisher, 2007). Under the VEBA agreement, GM would also be required to pay cash interest on a $\$ 4.37$ billion convertible note for the benefit of the trust fund, and the trustees of the fund would have the ability to convert this note to GM stock. For active GM workers, they were required to contribute four cents per quarter to the VEBA trust fund (Durbin and Krisher, 2007). The implementation of the VEBA trust fund was subject to both court and Securities and Exchange Commission approval (New York Times, 2007).

Another major provision of the tentative agreement was job security. In exchange for shifting the health care liabilities into VEBA, GM agreed to build current products and the next generation of products at sixteen of its eighteen U.S. assembly plants. Under the tentative deal, GM agreed to close only two plants, which included an engine plant in Livonia, Michigan and a stamping operation plant in Indianapolis, Indiana. In essence, GM made a multi-billion dollar commitment for the continuation of building specific engines, cars, and trucks at numerous plants across the United States. Some of the multibillion dollar commitments listed in the UAW contract included: a Detroit plant to build a battery operated car; a Kentucky plant to build a roadster; and revamping the company's big pick-up trucks in plants in Wisconsin, Michigan, and Indiana (McCracken and Kosdrosky, 2007). 
Under this provision, a stamping plant in Flint, Michigan and a small powertrain operation in Parma, Ohio also would be in jeopardy. Under the heading "Product Opportunities," the document stated that the UAW and GM would explore opportunities for current Flint employees. For the Parma plant, the document stated that no future powertrains would be allocated to the plant, but its stamping operation would continue with new generation products (Associated Press, 2007). Also, the Orion Township assembly plant, which made the Pontiac G6 had no product plans beyond 2013, and the Saturn Sky and Pontiac Soltice production would be moved from Wilmington, Delaware to Bowling Green, Kentucky after 2011 (Associated Press, 2007). Lastly, the Flat North engine plant would gain a new facility to build three "lean, agile flex engine modules at a new production site near the plant (Associated Press, 2007).

Under wage/benefit provisions of the tentative agreement, there were no pay raises allocated over the next four years, but rather lump sum payments of 3\%,4\%, and 3\% in the last three years of the contract. Additionally, a signing bonus of three thousand dollars would be given this year to every UAW member for the ratification of the contract. The agreement also created a two-tier structure to provide a lower wage between $\$ 12$ to $\$ 15$ per hour for newly hired workers for jobs that do not have a direct link to vehicle manufacturing such as sanitation workers (Yahoo News, 2007). Additionally, the new hires in non-production work would be given a 401(k) defined contribution plan (McCracken and Kosdrosky, 2007).

The tentative agreement also contained a special attrition program to reduce the ranks of higher-wage workers who would be replaced by newly hired employees at a lower wage. An early retirement buyout package for older workers would offer between $\$ 35,000$ and $\$ 140,000$ payments to those workers who elected to retire from GM. In 2006, GM offered a similar early retirement buyout package and it cost GM more than $\$ 6$ billion (Stoll, 2007). It has been estimated that approximately 18,000 workers have been with the company thirty or more years and would be eligible for retirement (McCracken and Stoll, 2007). On October 10, 2007, the 456-page landmark labor agreement was ratified by UAW workers by a margin of sixty-five percent of the total votes which represented less than the eighty percent or more initiatives backed the union leadership normally received (Valcourt, 2007).

\section{CHRYSLER, LLC-UNITED AUTOWORKERS NEGOTIATIONS}

With a deal completed at GM, the UAW focused its attention with the contract negotiations at Chrysler, LLC. At Chrysler, the UAW represented approximately 49,000 workers and was a relatively younger workforce than the workers at GM and Ford. The UAW approached these negotiations with the strategy of pattern bargaining. This bargaining approach was the union's long-held tradition of having a deal with one company as the set pattern for the other two auto companies (Stoll and McCracken, 2007). The UAW realized that this bargaining approach would be resisted by the new majority owner of Chrysler-Ceberas Capital Management, LLP. At the onset of formal negotiations, the UAW gave the required seventy two hour notice that it would no longer extend the labor agreement giving both parties only an eleven hour window for negotiations (Stoll, McCracken, and Valcourt, 2007). In retrospect, the tentative strike against Chrysler would have a relatively small impact since six plants were already scheduled to close for the upcoming week, due to soft auto sales experienced at Chrysler, LLC (Stoll, McCracken, and Valcourt, 22007).

For Chrysler, the primary goal was reduce labor costs since the company derived most of its $\$ 62$ billion revenue from North America, and its labor costs was equivalent to $\$ 75.86$ an hour for a UAW worker in contrast with $\$ 47.60$ at Toyota Corporation (Valcourt, 2007). Therefore, Chrysler was focused on gaining additional saving measures beyond the provisions of the landmark UAW-GM agreement. These saving measures would include: contributing less cash into VEBA, outsourcing some U.S. jobs to non-UAW workers, and fewer long-term commitments to build particular product lines beyond 2011 (Valcourt, 2007).

For the UAW, the challenge was in maintaining the tradition of pattern bargaining for its 49,000 union members at Chrysler. It was viewed that Chrysler was selected as the next bargaining entity because Ford needed major concessions from the UAW because of its weak financial position, as it posted a $\$ 12.6$ billion dollar loss in 2006 (McCracken and Stoll, 2007). Similar to its primary goal at the GM negotiations, the UAW also wanted to secure a commitment from Chrysler to protect jobs for its members. In February 2007, Chrysler had announced a 
restructuring plan which reduced eleven thousand hourly jobs and included a plant closure (Stoll and Valcourt, 2007).

After a six hour walkout at Chrysler, a tentative agreement was reached between the UAW and Chrysler. Similar to the agreement with GM, a multibillion-dollar trust fund (VEBA) was created to cover the cost of health care for UAW retirees. Additionally, a new two-tier wage and reduced benefit system was established for newly hired workers in certain noncore jobs, such as materials handlers (Stoll and Valcourt, 2007). The establishment of a two-tier system could potentially cause conflict in the workplace. For example, at the Chrysler's Belvidere, Illinois plant, a two-tier system was already in place, and workers had voiced their concern that the wage differences caused conflict among the workers (Valcourt, 2007). In return, Chrysler committed work for at least fifty of its fifty-nine facilities over the four year term of the labor agreement.

The ratification of the tentative labor agreement with Chrysler proved to be tense as heavy opposition occurred within the rank and file. Historically, once the UAW leadership agreed to a tentative national agreement, the contract typically has been ratified by its members. However, the last time a national contract, recommended by the UAW leaders, was voted down occurred in 1982, also by the workers at Chrysler (McCracken, Valcourt, and Stoll, 2007). The major opposition centered on the issue of job security because many rank and file members simply believed that the agreement did not provide enough firm assurances from Chrysler that it would produce future vehicles in U.S. plants which would protect union jobs (Valcourt, 2007). The tentative agreement was rejected by workers at: St Louis North pick-up truck plant; three transmission plants in Kokomo, Indiana; Detroit Axle facility; Minivan plant in St Louis South; Sport-Utility plant in Newark, Delaware (scheduled to close); and a small-car assembly facility in Belvidere, Illinois. As a result, the UAW leadership lobbied for the support of this contract as "their members faced tough choices, and we had a solid, democratic debate about this contract, and now we are going to come together as a union." Ultimately, the four-year labor agreement was approved by fifty-six percent of production workers who voted, and fifty-one percent of Chrysler skilled trades workers (Popely, 2007).

\section{FORD MOTOR COMPANY-UNITED AUTOWORKERS NEGOTIATIONS}

With the ratification of the new labor agreement with Chrysler completed, the UAW shifted its attention to Ford Motor company. Of the Big Three automakers, Ford Motor was viewed as the weakest and needed substantial labor-cost savings since it posted a net loss of $\$ 12.6$ billion in 2006 (Spector and McCracken, 2007). Given its dire financial situation, Ford Motor had implemented a restructuring plan in 2006 to eliminate fourteen thousand salaried jobs and twenty-five thousand to thirty thousand hourly positions by the end of 2008 (Spector and McCracken, 2007). Therefore, the primary bargaining goal for Ford Motor was to gain significant labor-cost saving measures, in order to return to profitability in the near future. On the other hand, the UAW sought job security for its 54,000 UAW members at Ford Motor, and desired plant and product commitments similar to those gained from GM and Chrysler.

After forty hours of "marathon negotiations," a tentative agreement was reached between Ford Motor and the UAW. Ford Motor promised to keep open two assembly plants (Wayne, Michigan and Louisville, Kentucky), and to avoid closing any other assembly plants in the United States during the term of the four year agreement. Additionally, commitments were made to build five new flexible body shops in unionized assembly plants, invest \$200 million in new technology and equipment in unionized stamping plants, and make a \$20 million tool-and-die investment in Dearborn, Michigan (Kosdrosky and Spencer, 2007).

In return for these commitments pertaining to job security, Ford Motor gained the ability to pay all new hires, including assembly-line workers, a lower starting wage of $\$ 12$ to $\$ 16$ an hour. This wage arrangement differed from the GM and Chrysler contracts, which provided a lower wage only to noncore jobs (Spector and McCracken, 2007). Similar to the GM and Chrysler labor agreements, a retiree health trust fund, referred to as VEBA, was established. Ford Motor would contribute $\$ 13.2$ billion into this fund with $\$ 6.5$ billion in a cash contribution, a $\$ 3$ billion secured note, a $\$ 3.3$ convertible debenture, and annual payments totaling $\$ 450$ million dollars (Kosdrosky and Spector, 2007). However, Ford Motor contributed less cash, about forty-five percent of the overall contribution, compared with fifty-five percent at GM and fifty percent at Chrysler (Spector and McCracken, 2007). The UAW members at Ford Motor approved the labor agreement when eighty-one percent of production 
workers voted in favor, and seventy-one percent of skilled-trades workers approved of the new labor agreement (Kosdrosky, 2007).

\section{CONCLUSION}

This paper examined the historic and landmark labor agreements between the UAW and the Big Three automakers. Both parties sought contractual provisions that were considered outside of the box to create a new paradigm for the American auto industry to survive and compete in the global economy. In the GM-UAW labor contract, GM established VEBA, a union-operated trust fund, in order to unload from its balance sheet more than $\$ 50$ billion in debts owed to the UAW retiree health care. Additionally, GM gained a new two-tier structure to provide a lower wage and benefits for newly hired workers who had no direct link to manufacturing a vehicle. In return, the UAW gained unprecedented product guarantees from GM pertaining to current and future generation of products at certain assembly facilities.

Following pattern bargaining, the UAW-Chrysler labor agreement also created a multibillion-dollar VEBA to cover the cost of health care for UAW retirees. The new two-tier wage and reduced benefit system was also established for newly hired worker in noncore jobs. In exchange for these concessions, the UAW protected some jobs for its members by securing a work commitment from Chrysler for at least fifty of its fifty-nine facilities over the term of the labor contract.

Similar to the GM and Chrysler, Ford Motor, viewed as the weakest of the Big Three automakers, also established a VEBA, but its overall cash contributions to the fund was considerably less than GM and Chrysler. Also, Ford gained the concession of paying all new hires, including assembly-line workers, a lower starting salary and reduced benefit package. In return for these wage and benefit concessions, the UAW gained a job security commitment from Ford Motor that two assembly plants would remain open, as well as any other assembly plant during the term of the four year agreement.

The three contracts negotiated between the UAW and the Big Three automakers are truly historic in significance. The contracts, each in its own way, reflect an awareness on the part of labor and management of the impact of a highly competitive global marketplace and the need to effect compromises in order for the American auto industry to remain viable, for management to profit, and for labor to be protected. Both sides must be credited with a measure of economic and social wisdom and responsibility. What remains uncertain is whether the compromises will be sufficient to expand US auto sales and increase profitability of management while permitting labor sufficient support to meet the increasing costs of energy, medical care, and other necessities impacted by inflation. This uncertainty also raises the question of whether, in the long term, these labor contracts will constitute good or bad economic decision making.

\section{AUTHOR INFORMATION}

John J. Lucas, Purdue University Calumet. Dr. Lucas was formerly the Industrial Relations Representative for Commonwealth Edison. He has experience in all facets of Human Resource Management including labor relations, benefits administration, human resource planning, and health education. He earned his Master of Science in Industrial Relations (MSIR) and Ph.D. degrees from Loyola University Chicago. He is an Associate Professor at Purdue University Calumet and teaches a variety of human resource management courses. His research interests are in the areas of labor relations, employee benefits, and health education. He is also a graduate of Purdue University Calumet.

Jonathan M. Furdek, Purdue University Calumet. Dr. Furdek earned his Ph.D. degree from the Krannert Graduate School of Management at Purdue University in Industrial Economics. He is an Associate Professor in Economics at Purdue University Calumet where he teaches courses in quantitative methods and operations management. His research interests involve pension benefits, manpower and facility planning, and supply chain management. 


\section{REFERENCES}

1. Durbin, Dee-Ann and Tom Krisher, GM, UAW win in contract deal, Yahoo News, 1 October, 2007.

2. Kosdrosky, Terry, Ford's UAW Members Ratify Labor Agreement, Wall Street Journal, 15 November 2007, SecA-2.

3. Kodrosky, Terry and Mike Spector, Ford Pact Gets Local Approval, Wall Street Journal, 6 November 2007, Sec A-3.

4. McCracken Jeffrey, Deal to Help GM Cost Gap With Rivals, Wall Street Journal, 11 October 2007, Sec A3.

5. $\quad$ McCracken, Jeffrey, UAW Talks Get Push, Wall Street Journal, 13 September 2007, Sec A-3

6. McCracken, Jeffrey and Terry Kodrosky, UAW Core Strategy Changes, Wall Street Journal 29-30 September 2007, Sec A-3.

7. McCracken, Jeffrey and John D. Stoll, Buyout Talks Loom for GM, UAW, Wall Street Journal, 5 October 2007, Sec A-3.

8. McCracken, Jeffrey and John Spector, Ford Is Likely to Follow Chrysler's Retreat, Wall Journal, 2 November Sec A-3.

9. McCracken, Jeffrey and John D. Stoll, UAW, GM Near Historic Deal on Retiree Health Costs, Wall Street Journal, 22-23 September 2007, Sec A-3.

10. McCracken, Jeffrey, Josee Valcourt and John D. Stoll, UAW Redoubles Chrysler Strategy, Wall Street Journal, 22 October 2007, Sec A-3.

11. New York Times, GM and Union Reach Tentative Agreement, 26 September 2007.

12. Popley Rick, UAW votes to approve Chrysler contract, Chicago Tribune, 28 October 2007, Sec 1-8.

13. Spector, Mike and Jeffrey McCracken, Ford and UAW Expect an Accord Soon, Wall Street Journal, 3-4 November 2007, Sec A-3.

14. Spector, Mike and Jeffrey McCracken, UAW Seeks to Build Support for Ford Deal, Wall Street Journal, 5 November 2007, Sec A-3.

15. Spector, Mike and Jeffrey McCracken, UAW Turns to Hard-Pressed Ford, Wall Street Journal 26 October 2007, Sec A-11.

16. Spector, Mike, Jeffrey McCracken and John D. Stoll, How Less Pay, More Risk 'Sells Itself' Wall Street Journal, 10 October 2007, Sec B-1.

17. Stoll, John D., GM Hangs on to Top Sales Spot Over Toyota, Wall Street Journal, 24 January 2008, Sec A10.

18. Stoll, John D. and Jeffrey McCracken, Fight Over Jobs Cost Cuts Spurs Walkout at GM, Wall Street Journal, 25 September 2007, Sec A -1 and 16.

19. Stoll, John D. and Jeffrey McCracken, GM's Labor Talks Show Progress, Wall Street Journal, 17 September 2007, Sec A-10.

20. Stoll John D. and Josee Valcourt, Chrysler, UAW Reach Agreement, Wall Street Journal, 11 October 2007, Sec A-3.

21. UAW. Org, GM workers strike on job security, economic issues, 24 September 2007.

22. Valcourt Josee, At Chrysler, UAW Saves Mopar Jobs, May Face Cuts, Wall Street Journal 12 October 2007, Sec A-10.

23. Valcourt Josee, More UAW Locals Reject Chrysler Deal, Wall Street Journal, 24 October 2007 Sec A-4.

24. Valcourt Josee, UAW Begins Drive to Push Through Chrysler Deal, Wall Street Journal, 19 October 2007, Sec A-15.

25. Valcourt Josee, UAW Leaders Push Chrysler Deal, Wall Street Journal, 20-21 October 2007, Sec A-3. 